\title{
Phenotypes of conjunctival inflammatory cells in sarcoidosis
}

\author{
A Karma, E Taskinen, H Kainulainen, M Partanen
}

\begin{abstract}
Phenotypes of the infiltrating mononuclear cells of the lower fornix conjunctiva of nine patients with sarcoidosis and six controls were studied using monoclonal antibodies and a modified immunoperoxidase method. Four patients had sarcoidosis of recent onset (duration of 2 years or less) and five patients had a chronic disease (duration of 3 or more years). The inflammatory cells in the sarcoid conjunctival specimens were predominantly $T$ lymphocytes, the vast majority of which were of $\mathbf{T}$ helper/inducer subtype expressing Leu$3 a+3 b$ positivity. The ratio of $T$ helper/inducer cells to $T$ suppressor/cytotoxic cells was 3.9 on average but only 0.9 in controls. Epithelioid cell granulomas were seen in three specimens in one case of recent onset and in two chronic cases comprising a marked amount (more than 15 cells/visual field) of cells bearing phenotypes of macrophages, $\mathbf{T}$ cells, $\mathbf{T}$ helper/inducer cells and HLA-DR antigen, and in smaller quantities of $T$ suppressor/cytotoxic cells. The mean number of all immunocompetent cell subtypes of specimens from newly diagnosed patients exceeded that of specimens from chronic patients. We believe that the sarcoid immune reaction in the conjunctiva is a dynamic process in which proliferation of immunocompetent mononuclear cells precedes the stage of granuloma formation.
\end{abstract}

Sarcoidosis is a lymphoproliferative disease of unknown aetiology characterised by widespread epithelioid cell granulomas in more than one system. Bilateral hilar lymphadenopathy and/or pulmonary infiltration are seen in nearly every patient but any organ or tissue can be affected. ${ }^{1}$ In three large clinical series consisting altogether of 1623 patients with sarcoidosis the frequency of ophthalmic manifestations varied between 25 and $38 \% . .^{2-4}$

Patients with active sarcoidosis often show enhanced humoral immune activity with hyperreactivity of B-cells, raised immunoglobulin levels, and circulating immune complexes. ${ }^{5}$ However sarcoidosis is above all a disease of increased immunological activity at specific disease sites leading to lymphocyte infiltration, monocyte recruitment, and granuloma formation. ${ }^{6}$ By monoclonal antibody techniques it has become possible to differentiate the phenotypes of the immunocompetent cell subpopulations in sarcoid tissues. These studies concerning mainly pulmonary ${ }^{67}$ but also extrapulmonary ${ }^{8-12}$ sarcoid involvements revealed the central role of the $T$ helper cells in initiating and modulating the granulomatous inflammatory response and the close interplay between the $T$ helper cells and activated macrophages. ${ }^{613}$
There are only a few studies concerning the utilisation of monoclonal antibodies in detecting the immunocompetent cells in conjunctival sarcoidosis. ${ }^{814}$ However the conjunctiva is an integral and active participant in the immunological defence system of the eye $e^{1516}$ and it is easily accessible for this kind of a study. By conventional histological examination $\mathrm{Karma}^{2}$ found epithelioid cell granulomas in $17 \%$ of all 218 conjunctival biopsies and $33 \%$ of the chronic cases in her unselected sarcoid population. Furthermore Kargioğlu and Brear ${ }^{17}$ identified granulomas in $71 \%$ of the sarcoid cases by random bilateral biopsy techniques. The purpose of this study was to examine with monoclonal antibodies the infiltrating cell profile in the conjunctiva of patients with recent onset and chronic sarcoidosis.

\section{Patients and methods}

Nine sarcoid patients (seven females and two males) aged 27 to 67 mean 52 (SD 13) years and six control patients aged 18 to 73 mean 46 (SD 22) years were studied. The clinical features of the sarcoid patients are shown in Table 1. Four patients (cases 1 to 4 ) had sarcoidosis of recent onset (duration 2 years or less) and five patients (cases 5 to 9) had chronic disease (duration 3 years or more). All individuals also had extrathoracic sarcoid manifestations in addition to pulmonary changes. In six patients sarcoidosis has been verified histologically. Four patients had uveitis two of whom additionally had retinal vasculitis (cases 6 and 7) and one patient also had an optic disc granulomatosis (case 7). One patient (case 2) without uveitis had a choroidal granuloma of suspected sarcoid origin. Patient 1 presented with a huge iris node. All subjects were assessed as having an active sarcoidosis based on clinical symptoms and/or elevated serum angiotensin converting enzyme (SACE). The chronic patients had higher mean SACE value (195 (SD 72) units/l) than the newly diagnosed individuals (81 (SD 27) units $/$, $\mathrm{p}=0.021$ ). Four patients (cases 1, 6, 7, and 9) were receiving systemic prednisolone therapy and two additional individuals (cases 1 and 5) were receiving topical dexamethasone at the time of the conjunctival biopsy.

In two patients (cases 6 and 8) the conjunctiva of the lower fornix looked quiet on slit-lamp examination, but in seven patients follicles in the lower fornix were seen and assessed as typical of sarcoidosis (Fig 1) in four patients (cases 4, 5, 7 and 9). We either biopsied one of the follicles or took a piece measuring $2 \times 2 \times 3 \mathrm{~mm}$ on average of the normal looking lower fornix conjunctiva. Forniceal conjunctival tissue was also obtained from six non-sarcoid patients undergoing 
Table 1 Clinical findings in nine patients with sarcoidosis

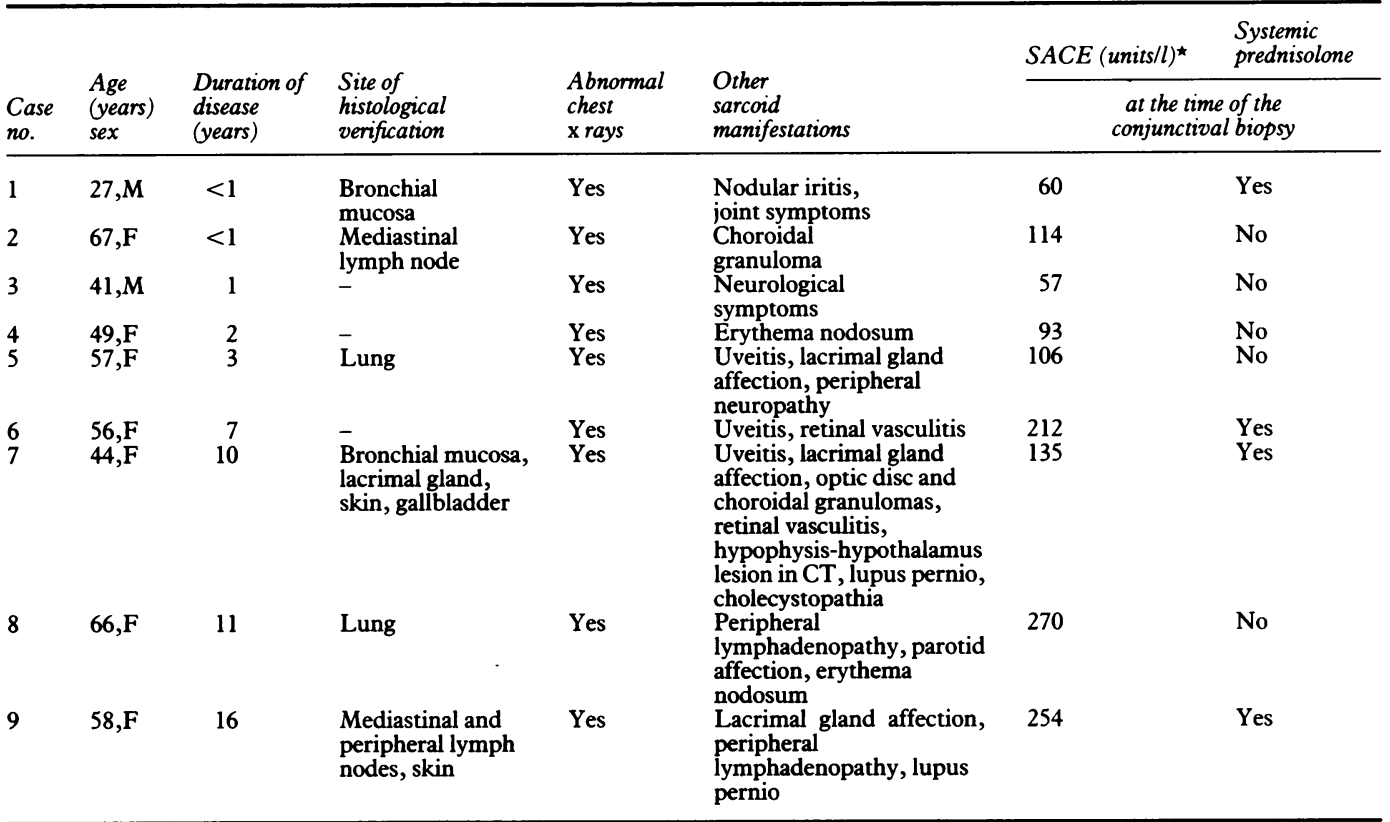

^Serum angiotensin-converting enzyme, range of normal values 35-155 units/l.

cataract (four), strabismus operation (one), or enucleation for choroidal melanoma (one). None of the control patients showed signs of nonspecific conjunctival inflammation but in one patient a few follicles were seen. Consent for the biopsy procedure was obtained from each subject.

The biopsy specimens were snap frozen and

Figure 1 Yellowish nodes typical of sarcoidosis in the lower fornix conjunctiva (arrows).

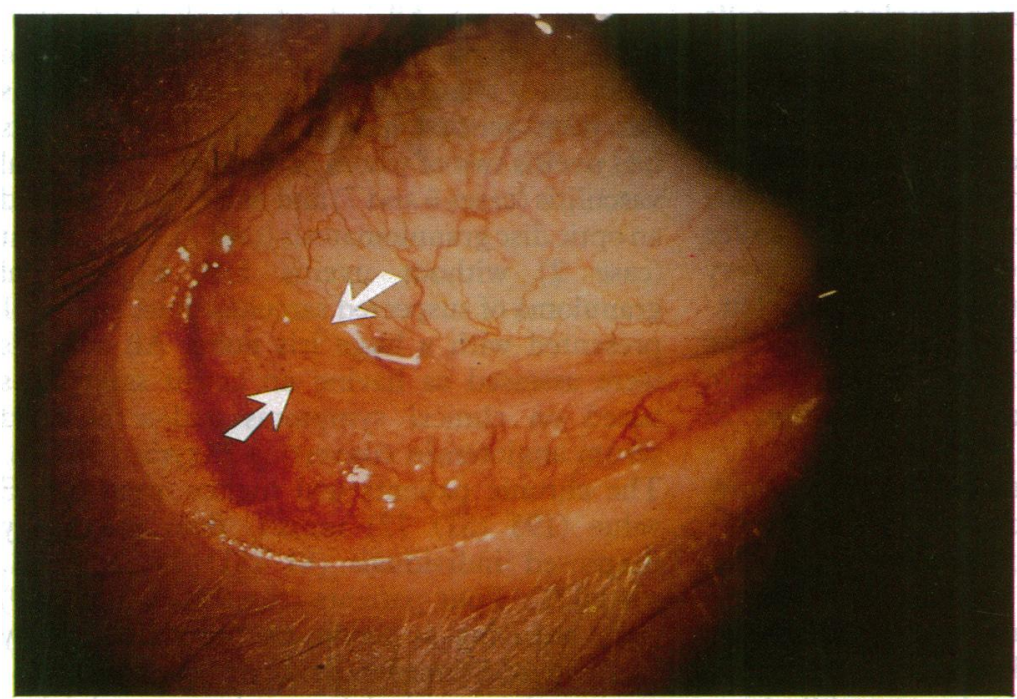

Table 2 Characterisation of monoclonal antibodies

\begin{tabular}{llll}
\hline & $\begin{array}{l}\text { Antigen } \\
\text { cluster } \\
\text { designation }\end{array}$ & $\begin{array}{l}\text { Dilution } \\
\text { of antibody }\end{array}$ & Predominant reactivity \\
\hline Antibody & CD3, CD2 & $1: 15$ & T cells \\
\hline $\begin{array}{l}\text { Anti-Leu-4+5b } \\
\text { Anti-Leu-3a+3b }\end{array}$ & CD4 & $1: 2$ & T helper/inducer cells \\
Anti-Leu-2a & CD8 & $1: 30$ & T suppressor/cytotoxic cells \\
Anti-Leu-14 & CD22 & $1: 4$ & B cells \\
Anti-Leu-7 & - & $1: 20$ & NK (natural killer) cells \\
Anti-Leu-M5 & - & $1: 40$ & Monocytes, macrophages \\
Anti-HLA-DR & - & $1: 60$ & B cells, monocytes \\
& & & macrophages, activated T cells \\
\hline
\end{tabular}

the primary monoclonal antibodies (Becton Dickinson Monoclonal Center) and their specificities are shown in Table 2. The secondary antibody was biotinylated horse anti-mouse IgG. Human lymph node served as a positive control. Two sections of each cell surface marker (primary antibodies) were prepared. One section was counterstained with Harris haematoxylin and the other was left unstained.

We scanned through all the specimens and depending on the size data were collected from 10 to 90 different consecutive $\times 40$ high power visual fields. The average number of positive cells/visual field for each primary antibody was obtained by dividing the total number of positively stained cells by the total number of visual fields counted. In addition the areas of granulomas and follicles were evaluated separately. The total number of positively stained cells in the area of granuloma/follicle was divided by the number of visual fields covering the granulomatous/follicular structure. The number of positively stained cells/visual fields was semiquantitatively determined in the area of the granuloma/follicle with the positivity being graded as follows: negative zero cells; mild from one to six cells; moderate from seven to 15 cells; and marked more than 15 cells. Statistical analyses were performed using the one-way analysis of variance.

\section{Results}

The phenotypic profile of the infiltrating mononuclear cells in the conjunctival specimens and that in the granulomatous/follicular areas of the sarcoid patients are shown in Tables 3 and 4. The inflammatory cells in the sarcoid conjunctival specimens were predominantly $\mathrm{T}$ lymphocytes identified by staining with anti Leu- $4+5 b$ antibody. The vast majority of the $T$ cells were, in all specimens except one (case 6), of T helper/ inducer subtype expressing Leu-3a+3b 
Table 3 Phenotypic profile of the inflammatory cells in the conjunctiva of the sarcoid patients

\begin{tabular}{|c|c|c|c|c|c|c|c|c|}
\hline \multirow{2}{*}{$\begin{array}{l}\text { Case } \\
\text { No }\end{array}$} & \multirow[b]{2}{*}{$L e u-4+5 b$} & \multirow[b]{2}{*}{$L e u-3 a+3 b$} & \multirow[b]{2}{*}{ Leu-2a } & \multirow{2}{*}{$\frac{L e u-3 a+b}{L e u-2 a}$} & \multirow[b]{2}{*}{ Leu-14 } & \multirow[b]{2}{*}{ Leu-7 } & \multirow[b]{2}{*}{ Leu-M5 } & \multirow[b]{2}{*}{$H L A-D R$} \\
\hline & & & & & & & & \\
\hline $\begin{array}{l}1 \\
2 \\
3 \\
4 \\
5 \\
6 \\
7 \\
8 \\
9\end{array}$ & $\begin{array}{c}15 \cdot 8 \\
23 \cdot 0 \\
65 \cdot 1 \\
25 \cdot 4^{\star} \\
42 \cdot 9 \\
8 \cdot 3 \\
20 \cdot 1^{\star} \\
7 \cdot 8 \\
20 \cdot 6^{\star}\end{array}$ & $\begin{array}{c}15 \cdot 3 \\
77 \cdot 9 \\
40 \cdot 4 \\
56 \cdot 6 \\
40 \cdot 8 \\
3 \cdot 8 \\
15 \cdot 1^{\star} \\
8 \cdot 7 \\
15 \cdot 6^{\star}\end{array}$ & $\begin{array}{c}2 \cdot 8 \\
25.9 \\
6 \cdot 6 \\
17 \cdot 0 \\
3 \cdot 1 \\
2 \cdot 5 \\
4 \cdot 1^{\star} \\
1.9 \\
3 \cdot 7^{\star}\end{array}$ & $\begin{array}{r}5 \cdot 5 \\
3 \cdot 0 \\
6 \cdot 1 \\
3 \cdot 3 \\
13 \cdot 2 \\
1 \cdot 5 \\
3.9 \\
4 \cdot 6 \\
4 \cdot 2\end{array}$ & $\begin{array}{c}15 \cdot 7 \\
15 \cdot 2 \\
80 \cdot 6 \\
19 \cdot 3 \\
6 \cdot 2 \\
0 \\
1 \cdot 4 \\
1 \cdot 1 \\
0.5\end{array}$ & $\begin{array}{l}1 \cdot 4 \\
0 \cdot 7 \\
1 \cdot 5 \\
0 \\
0 \cdot 2 \\
0 \\
0 \\
\text { ND } \\
\text { ND }\end{array}$ & $\begin{array}{r}1 \cdot 0 \\
7 \cdot 7 \\
9 \cdot 7 \\
24 \cdot 4 \\
5 \cdot 9 \\
0 \cdot 1 \\
12 \cdot 7 \\
2 \cdot 4 \\
4 \cdot 2\end{array}$ & $\begin{array}{c}16 \cdot 6 \\
22 \cdot 2 \\
80 \cdot 0 \\
140 \cdot 8 \\
11 \cdot 8 \\
2 \cdot 7 \\
26 \cdot 6^{\star} \\
5 \cdot 5 \\
3 \cdot 7^{\star}\end{array}$ \\
\hline $\begin{array}{l}\text { Mean }(S D) \\
\text { All } \\
\text { Cases 1-4 } \\
\text { Cases 5-9 } \\
\text { Ratio } \\
\text { (cases 1-4/ } \\
\text { cases 5-9) } \\
\text { p valuef }\end{array}$ & $\begin{array}{c}0 \text { of positively } \\
25 \cdot 4(16 \cdot 9) \\
32 \cdot 3(22 \cdot 2) \\
19 \cdot 9(26 \cdot 5)\end{array}$ & $\begin{array}{l}\text { ned cells in } \\
30 \cdot 5(18 \cdot 0) \\
47 \cdot 6(24 \cdot 4) \\
16 \cdot 8(14 \cdot 3)\end{array}$ & $\begin{array}{c}7 \cdot 5(6 \cdot 4) \\
13 \cdot 1(10 \cdot 4) \\
3 \cdot 1(0 \cdot 9)\end{array}$ & $\begin{array}{l}3 \cdot 9 \\
3 \cdot 7 \\
5 \cdot 7\end{array}$ & $\begin{array}{c}15 \cdot 6(19 \cdot 7) \\
32 \cdot 7(32 \cdot 0) \\
1 \cdot 8(2 \cdot 3)\end{array}$ & $\begin{array}{l}0.5(0.5) \\
0.9(0.7) \\
0.1(0 \cdot 1)\end{array}$ & $\begin{array}{r}7 \cdot 6(6 \cdot 9) \\
10 \cdot 7(9 \cdot 9) \\
5 \cdot 1(4 \cdot 8)\end{array}$ & $\begin{array}{l}34 \cdot 4(36 \cdot 3) \\
64 \cdot 9(58 \cdot 2) \\
10 \cdot 1(9 \cdot 9)\end{array}$ \\
\hline
\end{tabular}

*Indicates specimen in which epithelioid cells were identified. tUsing one-way analysis of variance after logarithmic transformation of data.
$\mathrm{ND}=$ no data.

positivity. The mean number of T helper/inducer cells outnumbered the $T$ suppressor/cytotoxic (Leu-2a positive) cells by 3.9 times on average being 3.7 in the newly onset patients and 5.7 in the chronic patients. In only one specimen (case 3) did the mean number of the B cells (Leu-14 positive) outnumber the $T$ cells. On the other hand in four of the five chronic cases $B$ cells were nearly or totally non-existent.

The positively stained cells in the conjunctival specimens were mainly located subepithelially (Figs 2 and 3) and scattered less frequently in substantia propria (Fig 3). A few scattered lymphoctyes and HLA-DR positive cells were also seen intraepithelially (Fig 3). Among diffuse infiltrations aggregates of diverse cell subtypes arranged more or less follicularly could be seen in nearly every section (Figs 4-7 and Table 4).

True granulomas (Figs 5-7) were observed in only three specimens, in one newly-onset case (no 4), and in two chronic cases (nos 7 and 9) (Tables 3 and 4). However epithelioid cells could not be identified in all sections in these specimens (Fig 5). The granulomas were composed predominantly of cells bearing monocyte (Leu-M5, Fig 5), T cell (Leu-4+5b, Figs 6 and 7), and T helper/inducer cell (Leu-3a+b) phenotypes. In two cases a moderate number of $\mathrm{T}$ suppressor/ cytotoxic cells were identified in the granulomas (cases 4 and 7, Table 4), but in one case (no 9) only a very few suppressor cells were detected. In two specimens the suppressor $\mathrm{T}$ cells were seen in the periphery of the granulomas but in the third they were seen in the middle of the granulomas as well. All sarcoid granulomas showed a marked positivity with anti HLA-DR antibodies.

There was a large difference in the number of all immunocompetent cells and their subtypes between the newly diagnosed and chronic cases (Table 3). The mean total numbers of T lymphocytes, $\mathrm{T}$ helper/inducer cells, $\mathrm{T}$ suppressor/ cytotoxic cells, and macrophages in the patients with newly onset sarcoidosis were $1 \cdot 6-4 \cdot 2$ times greater than the corresponding number of the cells in chronic sarcoidosis. The difference was statistically significant for $T$ suppressor cells $(p=0.067)$.

Furthermore the mean total number of HLADR positive cells and Leu-14 positive cells (B lymphocytes) in the newly onset cases exceeded the corresponding number of the chronic cases by $6.4(p=0.024)$ and $18 \cdot 2(p=0.002)$ times respectively.

In one control specimen taken from an evident follicle a marked positivity ( $>15$ cells/visual field) of $T$ lymphocytes and their subtypes was seen and in another specimen from a melanoma patient the HLA-DR positivity was marked. In the rest of the control specimens the number of immunocompetent cells was scanty. The ratio of $\mathrm{T}$ helper/inducer cells to $\mathrm{T}$ suppressor/cytotoxic cells of the control specimens ranged between 0.5 and 1.7 , the mean ratio being 0.9 .

\section{Discussion}

Sacks and coworkers ${ }^{19}$ studied, using monoclonal

Table 4 Phenotypic profile of the inflammatory cells in the conjunctival lymphoid follicles and granulomas

\begin{tabular}{|c|c|c|c|c|c|c|c|}
\hline Case & $L e u-4+5 b$ & $L e u-3 a+3 b$ & $L e u-2 a$ & Leu-14 & Leu-7 & Leu-M5 & $H L A-D R$ \\
\hline $\begin{array}{l}1 \\
2 \\
3 \\
4 \\
5 \\
6 \\
7 \\
8 \\
9\end{array}$ & $\begin{array}{l}++ \\
++ \\
+++ \\
+++^{\star} \\
0 \\
++ \\
++ \\
++ \\
+++^{\star}\end{array}$ & $\begin{array}{l}++ \\
+ \\
+++ \\
+++ \\
+ \\
++ \\
+++^{\star} \\
+++ \\
++\star\end{array}$ & $\begin{array}{l}+ \\
+ \\
++ \\
++ \\
+ \\
+ \\
++ \\
+ \\
+ \\
+\end{array}$ & $\begin{array}{l}+++ \\
++ \\
+++ \\
+++ \\
++ \\
0 \\
+ \\
+ \\
0\end{array}$ & $\begin{array}{l}+ \\
0 \\
+ \\
0 \\
0 \\
0 \\
0 \\
\text { ND } \\
\text { ND }\end{array}$ & $\begin{array}{l}0 \\
++ \\
+ \\
+++ \\
++ \\
0 \\
+++ \\
+ \\
+++\end{array}$ & $\begin{array}{l}++ \\
++ \\
+++ \\
+++ \\
+ \\
++ \\
+++ \\
++ \\
+++^{\star}\end{array}$ \\
\hline
\end{tabular}

Grading of positivity (mean number of positively stained cells/visual field): 0 (negative, zero cells), +(mild, from one to six cells), ++ (moderate, from seven to 15 cells), +++ (marked, more than 15 cells). 


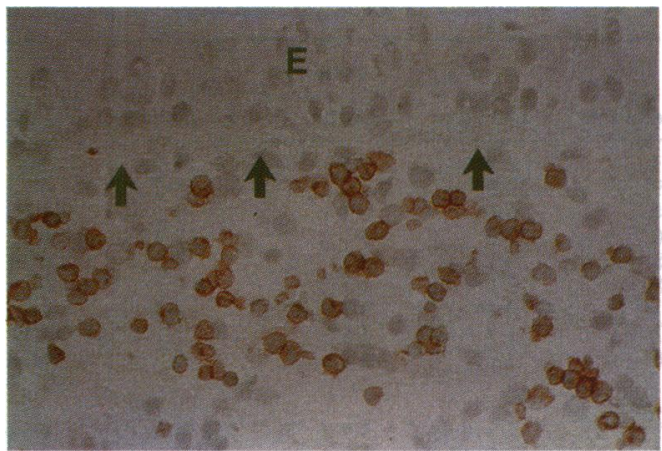

Figure 2 Case 6. Inflammatory subepithelial cells in the conjunctiva stained with anti $T$ cell antibody $($ Leu-4 $+5 b)$. $E$ indicates epithelium and arrows indicate demarcation between epithelium and substantia propria. Counterstained with Harris haematoxylin $(\times 310)$.

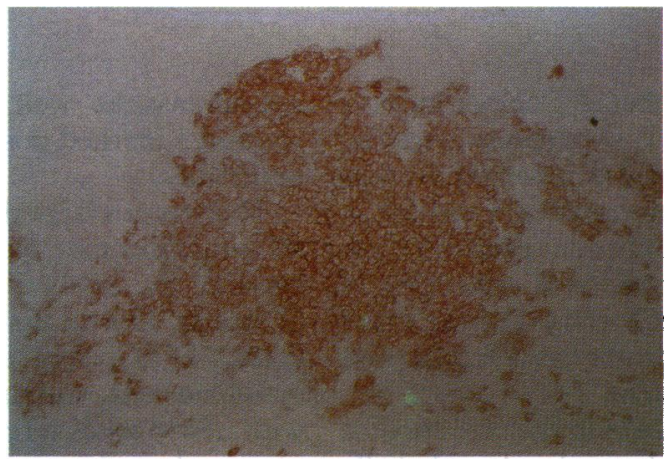

Figure 4 Case 8. Aggregates of $T$ helper/inducer cells (Leu-3a+3b positive) in the connective tissue of substantia propria $(\times 100)$.

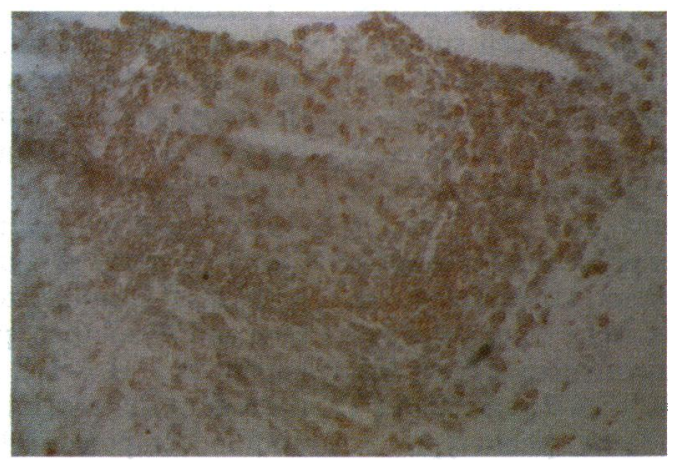

Figure 6 Case 4. Sarcoid granuloma in substantia propria showing marked positivity with anti $T$ cell antibody $(L e u-4+5 b)$. A vast majority of $T$ cells were of $T$ helperl inducer subtype. Counterstained with Harris haematoxylin $(\times 100)$.

antibodies, the lymphocytic subpopulations of normal human conjunctiva and found that the $T$ cells were the preponderant cell type with the greatest density in the substantia propria of the forniceal region and with a slight excess of $T$ suppressor cells over the $\mathrm{T}$ helper cells there. Bhan and coworkers ${ }^{20}$ on the other hand stated that in diseased conjunctiva such as in ocular pemphigoid, vernal conjunctivitis, and Mooren's ulcer the helper/inducer cells formed a major component of the $T$ cell population and only in graft-vs-host disease did the T suppressor/cytotoxic cells outnumber the $T$ helper cells in the cellular infiltrate of the conjunctival specimen.

We did not have conventional histological sections of the conjunctival specimens to be

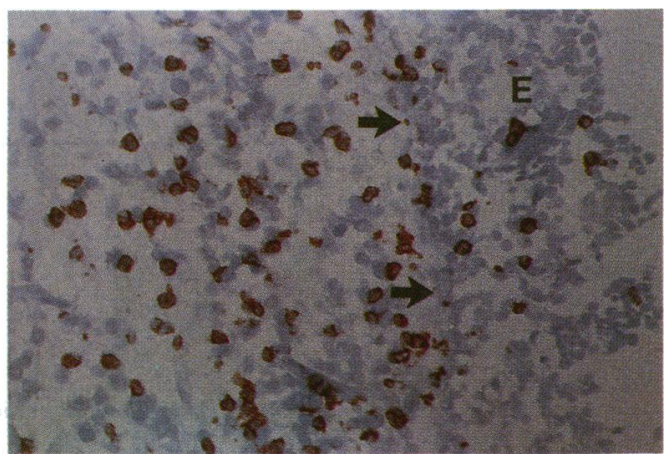

Figure 3 Case 2. Diffuse infiltration of T cells (Leu- $4+5 b$ positive) subepithelially and in the substantia propria. A few positive cells are seen also intraepithelially. $E$ indicates epithelium and arrows indicate demarcation between epithelium and substantia propria. Counterstained with Harris haematoxylin $(\times 260)$.

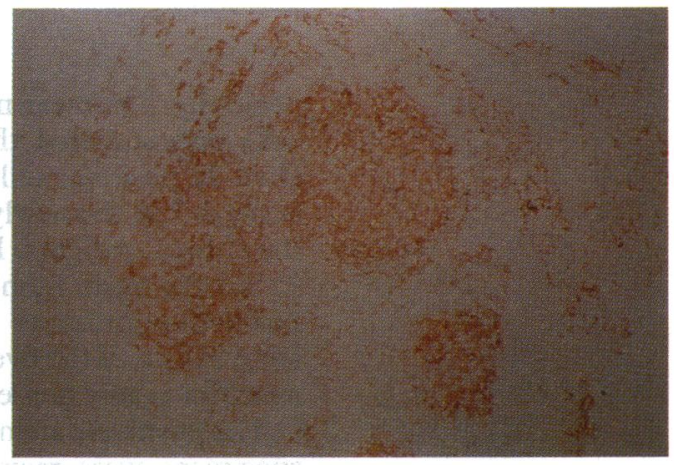

Figure 5 Case 7. Sarcoid granulomas in substantia propria showing marked positivity with antimacrophage antibody $($ Leu M5) $(\times 100)$.

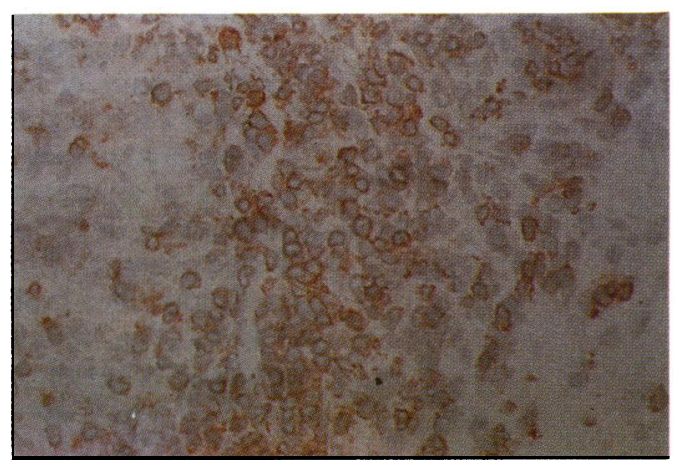

Figure 7 Case 4. Enlargement of Fig 6. There were many fewer $T$ cells among the central core of epithelioid cells. Counterstained with Harris haematoxylin $(\times 310)$.

compared with the frozen sections and not all the sections and stainings were fully successful. Epithelioid cell granulomas were found in only three specimens which could definitely be regarded as being of sarcoid origin. However because all patients had an active multisystem sarcoidosis we presume that the composition of the immunocompetent conjunctival cell population of all specimens had been modified by the sarcoid reaction.

In the present nine sarcoid conjunctival specimens the $T$ cells represented the main cell type, and among them the mean ratio of the $T$ helper/inducer to $\mathrm{T}$ suppressor/cytotoxic cells was nearly fourfold. This finding indicates that the $T$ helper cells are actively involved in the local cell-mediated immune reaction in the conjunctiva in sarcoidosis, and this is in agreement 
with the findings of others concerning pulmonary,,$^{78}$ skin, ${ }^{1011}$ peripheral lymphonodal, ${ }^{1221}$ intrabulbar, ${ }^{22}$ and conjunctival ${ }^{814}$ sarcoidosis. It can be suggested that in active sarcoidosis the conjunctiva like any other tissue can be a target site for the $T$ helper cells to be compartmentalised. Agni and coworkers ${ }^{14}$ in their series of 26 sarcoid conjunctival specimens from patients with a duration of sarcoidosis from 6 months to 18 years counted a much higher excess of $\mathrm{T}$ helper cells over $\mathrm{T}$ suppressor cells ranging from seven to 36 -fold. This indicates that their patients had a more active sarcoidosis than our patients at least at the conjunctival level. However their method of counting the positive cells as well as their selection of patients may have differed from ours.

Bronchoalveolar lavage studies have shown that lung $\mathrm{T}$ lymphocytes mainly $\mathrm{T}$ helper/inducer cells release lymphokines such as macrophage migration inhibitory and various macrophage activating factors that interact with monocytes/ macrophages to assist in the formation of a granuloma.$^{68}$ The same cascade of events can be supposed to occur in the affected conjunctiva in active sarcoidosis. In our sarcoid conjunctival specimens the number of macrophages was only a third of that of T cells. Apparently macrophages do not belong to the normal cellular population of the conjunctiva, ${ }^{19}$ and they are only secondarily drawn to the site of the conjunctival immune reaction. In contrast the pulmonary alveolar spaces of healthy non-smoking persons harbour mainly macrophages (more than $90 \%$ of cells in bronchoalveolar washings). ${ }^{8}$ Thus it is conceivable that in the alveolar tissue there is readiness to initiate the formation of granulomas. In the conjunctivae the granulomas possibly develop slowly under the influence of the continuous presence of antigen(s). If the assumed antigen exposure at the conjunctival level does not last long enough the local cell-mediated immune reaction may be extinguished before full evolution of granulomas takes place. This hypothesis is supported by the study of Agni and coworkers $^{14}$ who have shown the evolution pattern of the sarcoid conjunctival reaction from a small collection of macrophages surrounded by a few $\mathrm{T}$ helper lymphocytes to multiple aggregates of epithelioid and giant cells and a varying number of lymphocytes constituting dense cellular infiltrates.

Interestingly all inflammatory cell subtypes in the specimens from our newly diagnosed patients were more numerous on average than those in the specimens from our chronic patients. The increase of all immunocompetent cell subtypes may belong to the initial and active phase of sarcoid conjunctival reaction. The same phenomenon has been demonstrated in early and active intraocular ${ }^{22}$ and extraocular ${ }^{11}$ sarcoidosis as well as other active cell mediated immune disorders, for example sympathetic ophthalmia ${ }^{23}$ and has been suggested to be a by-product of the complex chemotactic factors liberated at the reaction site. Marked HLA-DR positivity in the conjunctival specimens of our newly diagnosed patients is also in keeping with this idea. HLA-DR is a marker considered vital in initiating immune response and is found in macrophages, B lymphocytes, and activated T lymphocytes. ${ }^{24}$ The excess of B cells in the conjunctival specimens from our newly diagnosed patients was especially high 18-fold. This may result from the polyclonal activation of the B cells at the conjunctival level. A phenomenon comparable with this is demonstrated in active pulmonary sarcoidosis.

In our chronic specimens there were mainly $\mathrm{T}$ cells with a mean excess of the $\mathrm{T}$ helper/ inducer cells 5.7-fold over the $\mathrm{T}$ suppressor/ cytotoxic cells in addition to macrophages and epithelioid cells concentrating in two cases in the granuloma areas. Consequently $\mathrm{T}$ helper cells seem to be essential both in the early and in the chronic conjunctival sarcoid reaction. We have shown previously ${ }^{25}$ that conjunctival granulomas confirmed by a conventional histological method may remain at the same site for years. In those cases an equilibrium between $T$ helper cells and $\mathrm{T}$ suppressor cells evidently has been achieved. Such an equilibrium possibly had been achieved in our patient 7 and 9. This steady state in chronic cases may also result in extinguishing the assumed initial polyclonal B cell activation with a consequent decrease of the conjunctival B cells. Long-term treatment with corticosteroids in three of five chronic cases may also have had a decreasing effect on all subtypes of conjunctival immunocompetent cells.

In conclusion our study demonstrates variations in the cellular components in the conjunctiva in recent onset and chronic sarcoidosis. We believe that sarcoid reaction in the conjunctiva is a dynamic process in which proliferation of the immunocompetent mononuclear cells precedes the stage of granuloma formation.

1 Mitchell DN, Scadding JG, Heard BE, Hinson KFV Sarcoidosis: histopathological definition and clinical diagnosis. F Clin Pathol 1977; 30: 395-408.

2 Karma A. Ophthalmic changes in sarcoidosis. Acta Ophthalmol $(K b h)$ 1979; 141 (suppl): 1-94.

3 James DG. Ocular sarcoidosis Ann NY Acad Sci 1986; 465: 551-63.

4 Obenauf CD, Shaw HE, Sydnor CF, Klintworth GK. Sarcoidosis and its ophthalmic manifestations. Am $\dot{f}$ Sarcoidosis and its ophthal
Ophthalmol 1978; 86: 648-55.

5 Hunninghake GW, Crystal RG. Mechanisms of hypergammaglobulinemia in pulmonary sarcoidosis. Site of increased antibody production and role of $\mathrm{T}$ lymphocytes. $\mathcal{F}$ Clin Invest 1981; 67: 86-92.

6 Thomas PD, Hunninghake GW. Current concepts of the pathogenesis of sarcoidosis. Am Rev Resp Dis 1987; 135: $747-60$

7 Crystal GW. Pulmonary sarcoidosis: a disorder mediated by excess helper T-lymphocytes activity at sites of disease activity. NEnglf Med 1981; 305: 429-34.

8 Semenzato G, Agostini C, Zambello R, et al. Activated T cells with immunoregulatory functions at different sites of involvement in sarcoidosis. Phenotypic and functional involvement in sarcoidosis. Phenotypic and
evaluations. Ann NY Acad Sci 1986; 465: 56-73.

9 Semenzato G, Pezzutto A, Chilosi M, Pizzolo G. Redistribution of $T$ lymphocytes in the lymph nodes of patients with of T lymphocytes in the lymph nodes of
sarcoidosis. NEngl $\mathcal{F}$ Med 1982; 306: 48-9.

10 Modlin RL, Hofman FM, Meyer PR, Sharma OP, Taylor CR, Rea TH. In situ demonstration of T lymphocyte subsets in granulomatous inflammation: leprosy, rhinosclerma and sarcoidosis. Clin Exp Immunol 1983; 51: 430-6.

11 Buechner SA, Winkelmann RK, Bank PM. T-cell subsets in cutaneous sarcoidosis. Arch Dermatol 1983; 119: 728-32.

12 Viale G, Codecasa L, Bulgheroni P, et al. T-cell subsets in sarcoidosis: an immunocytochemical investigation of blood, bronchoalveolar lavage fluid and prescalenic lymph node from eight patients. Hum Pathol 1986; 17: 476-81.

13 Hunninghake GW. Release of interleukin-1 by alveolar macrophages of patients with active pulmonary sarcoidosis. Am Rev Resp Dis 1984; 129: 569-72

14 Agni MR, Forattini F, Chílosi M, Cipriani A, DeCaro G, Semenzato G. Immunopathology of ocular sarcoidosis. Int Ophthalmol 1990; 14: 1-11.

15 Jackobiec FA, Lefkowitch J, Knowles DM. B- and T-

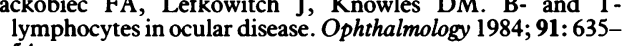
54

16 Chandler JW, Gillette TE. Immunologic defense mechanisms of the ocular surface. Ophthalmology 1983; 90: 585-91. 
17 Kargioğlu ZA, Bear R. Conjunctival biopsy in sarcoidosis. Am 7 Ophthalmol 1985; 99: 68-73.

18 Hsu S-M, Raine L, Fanger H. Use of avidin-biotin-peroxidase complex (ABC) in immunoperoxidase techniques: a comparison between ABC and unlabeled antibody (PAP) comparison between $\mathrm{ABC}$ and unlabeled antibody

19 Sacks EH, Wieczorek R, Jakobiec FA, Knowles DM. Lymphyocytic subpopulations in the normal human conjunctiva. A monoclonal antibody study. Ophthalmology 1986; 93: 1276-83.

20 Bhan SK, Fujikawa LS, Foster CS. T-cell subjects and Langerhans cells in normal and diseased conjunctiva. $A m \mathcal{F}$ Ophthalmol 1982; 94: 205-12.

21 van den Oord JJ, de Wolf-Peeters C, Facchetti F, Desmet VJ.
Cellular composition of hypersensitivity-type granulomas: immunohistochemical analysis of tuberculous and sarcoidal lymphadenitis. Hum Pathol 1984; 15: 559-65.

22 Chan CC, Wetzig RP, Palestine AG, Kuwabara T, Nussenblat of ocular sarcoidosis. Arch Ophthalmol 1987; 105: 1398-402.

23 Chan CC, Nussenblatt RB, Fujikawa LS, et al. Sympathetic ophthalmia. Immunopathological findings. Ophthalmology 1986; 93: 690-5.

24 Winchester RJ, Kunkel HG. The human Ia system. In: Dixon FJ, Kunkel HG, eds. Advances in immunology. New York: Academic Press, 1979: 221-292.

25 Karma A, Huhti E, Poukkula A. Course and outcome of ocular sarcoidosis. Am f Ophthalmol 1988; 106: 467-72.

\section{FIFTY YEARS AGO}

\section{The Education of an Ophthalmic Surgeon}

Many ophthalmic surgeons in Britain in the past have slipped into their particular niches fortuitously; and not only ophthalmic surgeons, for we remember the story of a young man waiting for an ophthalmic vacancy becoming eventually a distinguished obstetrician. This was a good many years ago; but when Brudenell Carter was appointed ophthalmic surgeon at St George's Hospital in 1870 it was settled that part of his hospital duties was to undertake the responsibility of the obstetrician's holiday work. This was no particular hardship, for as Carter had been in general practice until he was $\mathbf{4 0}$ years old he was quite competent to deal with straightforward or difficult cases of labour. Times have changed since then but we feel quite sure that those who have entered specialists' work without any experience of general practice first have missed a great deal. The converse, when an elderly general practitioner gives up general practice for ophthalmology, is not at all common; but has occurred in a few instances. Brf Ophthalmol 1942; 26: 75. 